\title{
Germination and Seedling Growth of Genotypes Crambe abyssinica Submitted to Water Deficit
}

\author{
Priscila C. S. Braga ${ }^{1}$, João Paulo R. Martins ${ }^{1}$, Mauro V. Pacheco ${ }^{2}$, Railda M. Borges ${ }^{1}$, Robson Bonomo ${ }^{1}$,

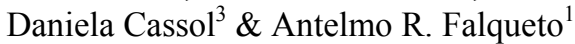 \\ ${ }^{1}$ Department of Agrarian and Biological Science, Federal University of Espírito Santo, São Mateus, ES, Brazil \\ ${ }^{2}$ Academic Unit of Agrarian Sciences, Federal University of Rio Grande do Norte, Macaíba, RN, Brazil \\ ${ }^{3}$ Department of Botany and Plant Sciences, University of California, CA, USA \\ Correspondence: Priscila da Conceição de Souza Braga, Department of Agrarian and Biological Science, Federal \\ University of Espírito Santo, 29932-540 São Mateus, ES, Brazil. Tel: 55-273-312-1548. E-mail: \\ priscila.csbraga@gmail.com
}

$\begin{array}{lc}\text { Received: May 25, } 2019 & \text { Accepted: July 17, } 2019 \quad \text { Online Published: September 15, } 2019 \\ \text { doi:10.5539/jas.v11n15p23 } & \text { URL: https://doi.org/10.5539/jas.v11n15p23 }\end{array}$

\begin{abstract}
Determining drought tolerance in plants is an increasingly important feature due to the reduction of water resources, since water stress is one of the main environmental factors that limit agricultural growth and productivity. The objective of this study was to evaluate the tolerance of crambe (Crambe abyssinica Hochst) genotypes submitted to water stress induced by polyethylene glycol during germination and early growth of seedlings. A randomized block experimental design was used in a factorial scheme consisting of five crambe genotypes (FMS Brilhante, FMS CR 1203, 1307, 1312 and 1326) and five levels of osmotic potential [0.0 (control), $-0.2,-0.4,-0.5$ and $-0.6 \mathrm{MPa}$ ] in five replicates of 40 seeds. Germination rate (\%), normal seedling development (\%), germination speed index, root and shoot length, total fresh matter, and water content of seedlings (\%) were analyzed. Physiological quality of seeds and initial development of crambe genotypes was improved in the group submitted to $\Psi_{\mathrm{W}}=-0.2 \mathrm{MPa}$. Germination and vigor index of crambe seeds were hampered by reduction of the potential to $-0.4 \mathrm{MPa}$. The genotype FMS CR 1203 was the most tolerant to water stress, whereas FMS CR 1307 and 1312 were the most sensitive, as corroborated by PCA.
\end{abstract}

Keywords: abiotic stress, FMS Brilhante, osmotic potential, polyethylene glycol, seed

\section{Introduction}

Water deficit is one of the most important and complex environmental factors limiting the germination of seeds (Viçosi et al., 2017) and development of seedlings (Machado et al., 2017). In seeds, water deficit reduces the turgor pressure, negatively affecting the expansion and growth of cells (Bewley \& Black, 1994), reducing the availability of oxygen, gas exchanges and synthesis of enzymes and hormones for digestion, translocation and assimilation of reserves (Marcos-Filho, 2005), resulting in a reduced germination speed index (GSI) (Kader \& Jutzi, 2002). This exposes the seeds to the action of pathogens and attacks by insects and other pests (Machado et al., 2017). Water deficit also causes an increase in the dry weight of embryos, due to the need for osmotic adjustment, associated with the accumulation of compatible solutes (Gill et al., 2003). According to Patanè et al. (2013), water deficit leads to more concentrated root tissue and lower water content in the roots. Furthermore, in genotypes more sensitive the metabolic signaling that regulates gene expression during water deficit can be reduced (Coelho et al., 2010), consequently stunting the growth of the hypocotyl and radicle (Viçosi et al., 2017).

Plants have developed many strategies to maintain growth when water availability is restricted or inconsistent (Silva et al., 2016), such as ionic homeostasis and activation of the enzyme antioxidant system, to promote cell detoxification and growth regulation (Zhu, 2001; Silva et al., 2017). However, these responses are generally more pronounced in genotypes that are tolerant to water deficit. According to Kappes et al. (2010), experiments involving germination of seeds under different osmotic potentials are important for selection of genotypes that are tolerant or susceptible to water deficit. 
Several studies have investigated the germination of seeds submitted to different osmotic potentials, to screen for genotypes that are tolerant to water deficit (Machado et al., 2017; Viçosi et al., 2017; Paiva et al., 2018). These studies have the objective of improving the establishment of crops in the field. Machado et al. (2017) observed a higher germination rate, germination first count, fresh and dry matter in Crambe abyssinica (Hochst.) FMS CR 1101 genotype submitted to different osmotic potentials induced by polyethylene glycol 6000 (PEG 6000), which was attributed to higher tolerance to water deficit compared with the FMS Brilhante genotype. The water stress tolerance levels of seeds of cowpea [(Vigna unguiculata L. (Walp)] and the arabica coffee (Coffea arabica L.) varieties Red Bourbon and Mundo Novo compared to cultivar BA-10 utilizing PEG 6000 were evaluated (Paiva et al., 2018; Almeida et al., 2018). In these studies, it was possible to differentiate between drought-resistant and drought-sensitive cultivars by observing the level of seed germination and early development of seedlings. PEG 6000 is a chemically inert and nontoxic product that simulates low water potentials without being absorbed by seeds, due to the large size of its molecules (Villela et al., 1991). The application of PEG 6000 is one of the most widely used methods to identify genotypes that are tolerant to water deficiency by osmotic stress.

Crambe (Crambe abyssinica Hochst.) is an annual plant belonging to the family Brassicaceae, grown for industrial purposes as an oilseed crop. The oil is highly valuable and has multiple uses, such as to make plastics, lubricants and biodiesel (Carlsson et al., 2007). The oil content of the seeds ranges from 36 to $38 \%$ (Pitol et al., 2010), higher than that of soybeans (Faria, 2014). Because it does not compete with oilseed crops used to obtain edible oils, its cultivation is expanding in Brazil, particularly to produce vegetable insulating oil (Oliveira et al., 2015).

According to Pitol et al. (2012), new varieties are being tested to expand its cultivation and improve yield in Brazil. At present, FMS Brilhante is the only genotype registered in Brazil. However, the genotypes FMS CR 1312 and 1307 are considered to be candidate materials for pre-launch, and FMS CR 1213 and 1326 are still being tested by Brazil (Oliveira et al., 2015). The identification of genetic materials with high germinability and good development under environmental stress conditions like water deficit is necessary to improve productivity and expand the culture to regions characterized by low precipitation. Therefore, this study aimed to evaluate the tolerance of five crambe genotypes submitted to water stress during germination and early growth of seedlings.

\section{Methods}

The experiment was carried out at the Laboratory of Plant Ecophysiology of Federal University of Espírito Santo (UFES), in São Mateus, ES, Brazil, using seeds of five crambe genotypes (Crambe abyssinica Hochst., FMS Brilhante, FMS CR 1203, 1307, 1312 and 1326), obtained from the Mato Grosso do Sul Foundation (MS Foundation), an agency for research and diffusion of agricultural technologies.

Water deficit was induced by polyethylene glycol (PEG 6000) treatments. Four solutions with $\Psi_{\mathrm{w}}=-0.2,-0.4$, -0.5 , and -0.6 MPa were applied (distilled water was used as the control treatment), according to the levels established by Villela et al. (1991). To avoid hypoxia by flooding the seeds, which strongly inhibits germination, special care was taken during application of the solutions. The seed moisture level was determined by the oven-drying method, at $105 \pm 3{ }^{\circ} \mathrm{C}$ for 24 hours (Brasil, 2009).

The crambe seeds were sterilized with solutions of $70 \%$ ethanol for 2 minutes, $1 \%$ (v/v) sodium hypochlorite for $20 \mathrm{~min}$. and the fungicide Ridomil ${ }^{\circ}$ for $10 \mathrm{~min}$., followed by triple washing with autoclaved distilled water. The seeds were then planted in a gerbox box $(11 \times 11 \times 3 \mathrm{~cm})$ containing washed sand moistened to $60 \%$ of retention capacity (Brasil, 2009) and placed in a growth room at $25^{\circ} \mathrm{C}$ with photoperiod of $16 \mathrm{~h} \mathrm{light}$ and $8 \mathrm{~h}$ dark.

The germination rate $(\% \mathrm{G})$ was determined according to the primary root emergence criterion. The percentage of normal plants (\%NP) and germination speed index (GSI) were measured on the seventh day after sowing according to Brasil (2009), following Equations 1 and 2, as described by Maguire (1962).

$$
\begin{aligned}
\% \mathrm{G} \text { or } \% \mathrm{NP} & =(\mathrm{\Sigma ni} / \mathrm{N}) \times 100 \\
\mathrm{GSI} & =(\mathrm{G} 1 / \mathrm{N} 1)+(\mathrm{G} 2 / \mathrm{N} 2)+(\mathrm{Gn} / \mathrm{n})
\end{aligned}
$$

Where, $\% \mathrm{G}$ or $\% \mathrm{NP}$ : percentage of germination by radicle emission or percentage of normal plants, respectively; $\Sigma$ ni: total number of germinated seeds; N: number of seeds placed to germinate; GSI: germination speed index; G1, G2, Gn: number of seeds germinated on the first, second and last day and N1, N2 and Nn: days since sowing on the first, second and last day.

At the end of the germination test, the primary root and hypocotyl of normal seedlings of each replicate were measured using a centimeter ruler, and the results were expressed in $\mathrm{cm}$ seedling ${ }^{-1}$. Furthermore, to determine 
shoot and root dry matter, the seedlings were cut and placed in paper bags, dried in a forced-air oven at $65^{\circ} \mathrm{C}$ for $72 \mathrm{~h}$ and weighed on an analytical scale $(0.0001 \mathrm{~g})$. The results were expressed in $\mathrm{g}$ seedling ${ }^{-1}$.

Finally, the water content of the seedlings was determined using the fresh and dry weight values, according to Equation 3.

$$
\mathrm{WC}=[(\mathrm{Wi}-\mathrm{Wf} / \mathrm{Wi})] \times 100
$$

where, WC: water content of the seedlings (\%); Wi: initial weight (fresh) and Wf: final weight (dry).

The experiment was carried out in randomized block design with five replicates containing 40 seeds each. The factors were five water potential levels [control (distilled water), $-0.2,-0.4,-0.5$, and $-0.6 \mathrm{MPa}$ ] and five crambe genotypes. The data were submitted to analysis of variance (ANOVA) and the means of the factors (genotypes and osmotic potential levels) were compared using the Tukey test $(p<0.05$ or $p<0.001)$, calculated by the Sisvar ${ }^{\circledR}$ program (Ferreira, 2011). Principal component analysis (PCA) were performed to visualize the data globally and in order to identify the correlations between the osmotic potential treatments and the genotypes variation using $\mathrm{R}$ software ( $\mathrm{R}$ Core Team, 2018). The data obtained in the evaluation of each treatment and genotype were initially standardized and PCA was conducted using the Factor Mine R package (Le et al., 2008).

\section{Results and Discussion}

The seed moisture content varied significantly $(\mathrm{p} \leq 0.001)$ among the crambe genotypes evaluated (Table 1$)$. The lowest seed moisture values were observed for the FMS Brilhante and FMS CR 1203 genotypes (5.65 and 5.69, respectively). In contrast, the highest values were recorded for FMS CR 1307 (Table 1). According to Marco-Filho (2005), the seed moisture content is related to seed vigor, since free water in the tissues increases various reactions, including those involved in seed deterioration, such as increased respiration, inducing the synthesis of adenosine triphosphate (ATP) (Kibinza et al., 2006) and malondialdehyde (MDA), in turn reducing cell membrane protection and increasing lipid peroxidation (Zhang et al., 2018), which occurs through the cascade of superoxide radicals $\left(\mathrm{O}_{2}{ }^{-}\right)$, hydrogen peroxide $\left(\mathrm{H}_{2} \mathrm{O}_{2}\right)$ and hydroxyl radicals $\left(\mathrm{OH}^{-}\right)$(Noctor \& Foyer, 1998; Zhang et al., 2018). In this study, although all crambe genotypes showed adequate seed moisture values (e.g., values $<9$ b.u., see Table 1), the higher seed moisture values reported for FMS CR 1307 may indicate increased biochemical reactions, which consequently increases the chances of seed deterioration (Cardoso et al., 2012).

The interaction between crambe genotypes and osmotic potential levels was significant $(\mathrm{p} \leq 0.001)$ for germination rate (\%), normal seedling percentage (\%), germination speed index (GSI), radicle and hypocotyl length and fresh matter (Figures 1-4). Total dry matter (DM) of the seedlings was significantly influenced ( $\mathrm{p} \leq$ 0.001 ) by the isolated factors, genotypes and osmotic potential levels (Table 2).

Overall, the crambe seeds germinated at all the osmotic potentials tested. Higher germination occurred when seeds were treated at $-0.2 \mathrm{MPa}$ (Figure 1A). Under $\Psi_{\mathrm{s}}$ higher than $-0.4 \mathrm{MPa}$, significant decreases in germination occurred for all genotypes and reached minimums of $17.5 \%, 22 \%, 12 \%, 15 \%$ and $9.5 \%$ for FMS Brilhante, FMS CR 1203, 1307, 1312 and 1326, respectively, at $-0.6 \mathrm{MPa}$ (Figure 1A). Furthermore, in the control group (0.0 $\mathrm{MPa}$ ), the germination declined by about $22.7 \%, 82.1 \%, 77.5 \%$ and $36.2 \%$ in the FMS Brilhante, FMS CR 1307 , 1312 and 1326 genotypes, respectively.

Table 1. Degree of seed moisture of different genotypes Crambe abyssinica Hochst

\begin{tabular}{ll}
\hline Genotypes Crambe abyssinica & Degree of seed moisture (\%) \\
\hline FMS Brilhante & $5.65 \pm 0.078 \mathrm{C}$ \\
FMS CR 1203 & $5.69 \pm 0.076 \mathrm{C}$ \\
FMS CR 1307 & $6.36 \pm 0.064 \mathrm{~A}$ \\
FMS CR 1312 & $5.99 \pm 0.073 \mathrm{~B}$ \\
FMS CR 1326 & $6.11 \pm 0.085 \mathrm{AB}$ \\
CV $(\%)$ & 1.13 \\
\hline
\end{tabular}

Note. Means followed by the same letter in the column do not differ by Tukey test at 0.001 probability level $( \pm \mathrm{SD})$.

At the start of the germination process, the seeds are water dependent (phases I, II and II) (Bewley, 1997). During phase III, which is characterized by cell elongation, radicle emission occurs and the rate of seed 
imbibition tends to decelerate (Bewley, 1997; Bove et al., 2001). In this study, the reduction of germination reported for the FMS Brilhante, FMS CR 1307, 1312 and 1326 genotypes in the control group $\left(\Psi_{\mathrm{s}}=0 \mathrm{MPa}\right)$ may have occurred due to fast seed imbibition, which can cause damages to the embryo, as reported by Bewley and Black (1994). Furthermore, the reduction of germination from -0.4 MPa on ward suggests osmotic interference in enzymatic activity, delaying meristematic development and retarding root emergence (Bewley et al., 2013). According to Marco-Filho (2015), low germination rates are related to membrane disorganization, followed by tissue death in different parts of seeds, especially meristematic tissues. In this study, the seed germination of all crambe genotypes was inhibited at $-0.4 \mathrm{MPa}$, except for FMS CR 1307. Under in not adequate water potential, inhibition of seed imbibition capacity occurs, which limits the activation of the main metabolic pathways that act directly or indirectly on seed germination (Marcos-Filho, 2005).

The percentage of normal plants was zero for both FMS CR 1307 and 1312 genotypes when the seeds were treated at $-0.6 \mathrm{MPa}$. Therefore, the seeds of FMS CR 1307 and 1312 that showed some germination (denoted by radicle emission) (Figure 1A) did not generate normal seedlings (Figure 1B). The formation of abnormal seedlings of these crambe genotypes treated at $-0.6 \mathrm{MPa}$ suggests dysfunction and/or damage to the biomembrane system, caused by the progressive loss of protoplasmic turgor and increased concentration of cellular solutes (Bruni \& Leopold, 1992). The lower values of germination and normal plants (Figure 1A and B) reported for both crambe genotypes may indicate greater susceptibility to water deficit caused by PEG.

Reductions in GSI occurred in all genotypes with the reduction of water potential (Figure 1C). According to Dell'Aquila (1992), reduction in GSI values is a common response to water deficit and can be attributed to the impaired synthesis of proteins in embryonic tissues due the low hydration. The FMS CR 1203 genotype showed higher values of GSI when submitted to 0.0 and $-0.4 \mathrm{MPa}(14.4,3.2$, respectively). In contrast, lower GSI values were reported at 0.0 and $-0.2 \mathrm{MPa}$ (7.2 and 7.9, respectively) for FMS CR 1307 and $-0.4 \mathrm{MPa}$ (1.5) for FMS CR 1312. Rapid germination generally corresponds to seed vigor, leading to faster emergence of seedlings in the field (Marcos-Filho, 2015). In this study, the higher GSI observed for the FMS CR 1203 genotype suggests higher probability that the seeds reached the next phase of the biocycle (Oliveira et al., 2015), because an increase in the GSI under water deficit conditions indicates less susceptibility to pathogens, insects and other pests (Machado et al., 2017), increasing the success of seedling development. 

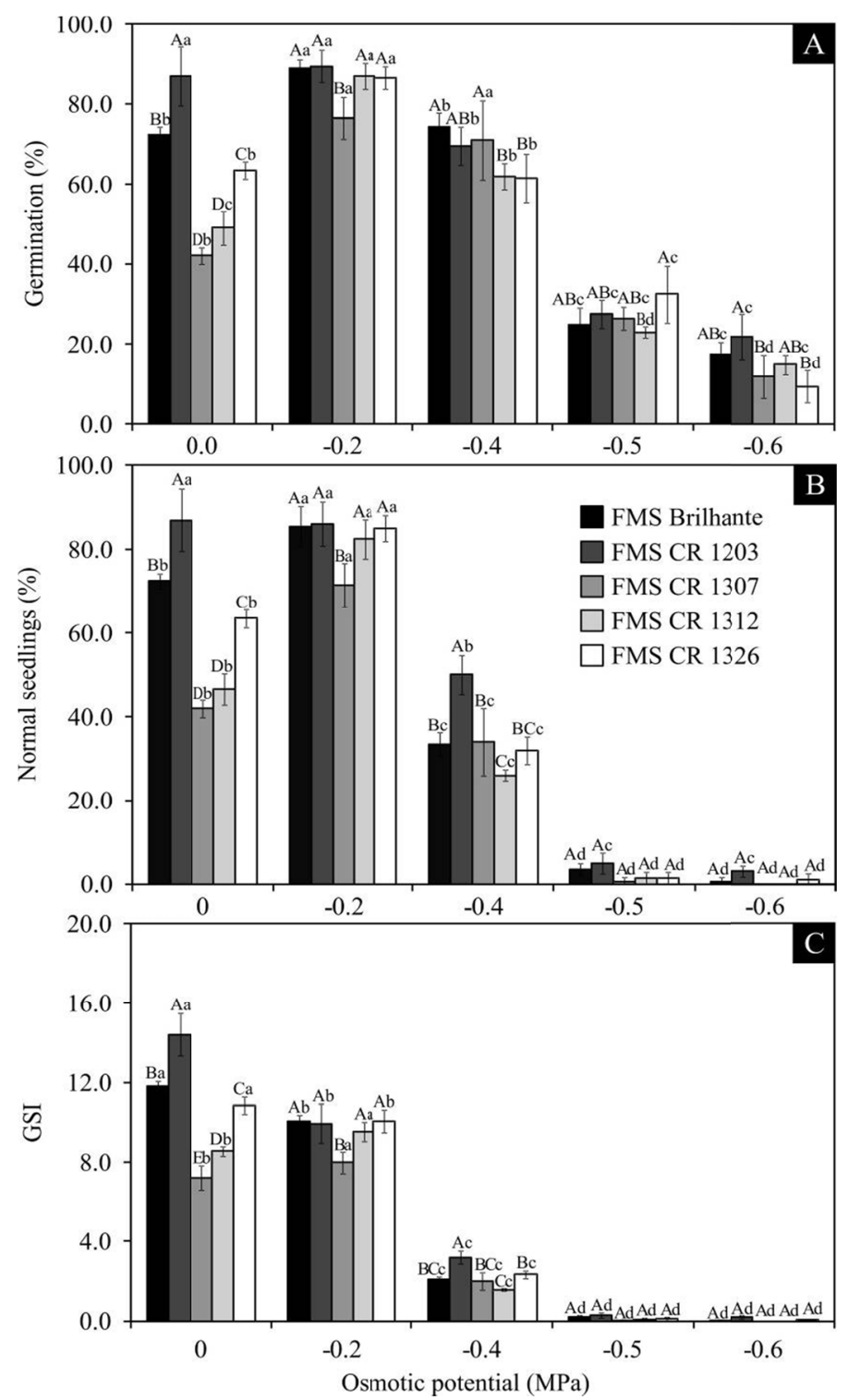

Figure 1. Gemination (A), normal seedlings (B) and germination speed index-GSI (C) of Crambe abyssinica seeds, genotypes FMS Brilhante, FMS CR 1203, 1307, 1312 and 1326, under different osmotic potentials. SD is shown, the same letters mean no significant difference (small letter: osmotic potentials, capital letter: different genotypes) $(p \leq 0.001)$

The crambe seedlings showed different growth patterns when submitted to different osmotic potentials (Figure 2 and 3). However, up to the potential of $-0.5 \mathrm{MPa}$, all seedlings had long and thin primary roots, coated with numerous root hairs, thin and elongated hypocotyl and green or greenish cotyledons (Figure 2). At $\Psi \mathrm{s}=-0.6$ MPa, only FMS CR 1307 and 1312 genotypes produced seedlings classified as abnormal according to Brasil (2009). Seedlings of FMS CR 1307 had underdeveloped and yellowish cotyledons. Furthermore, seedlings of FMS CR 1312 showed under developed hypocotyl and poor root growth. 

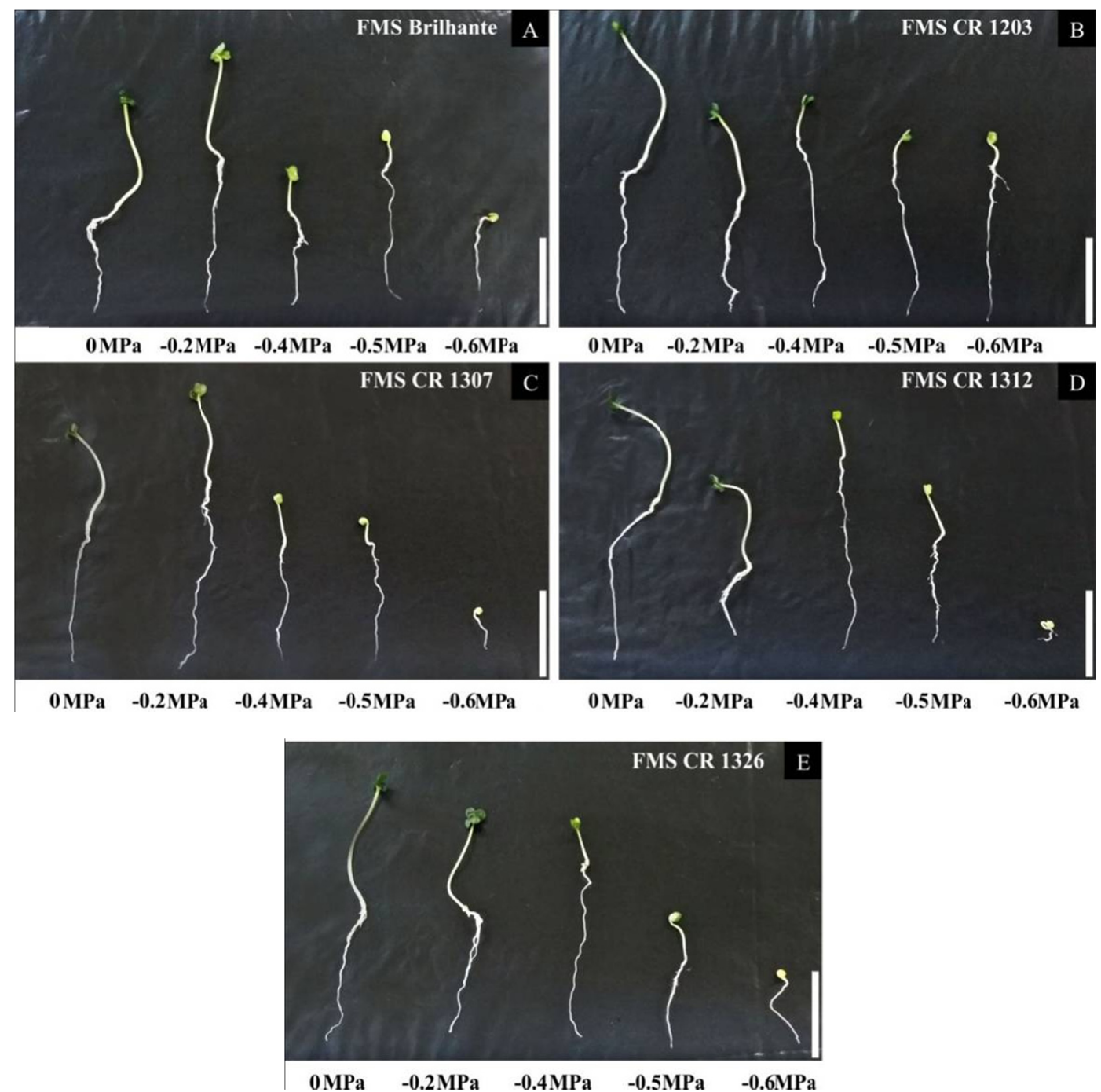

Figure 2. Seedlings of different genotypes of crambe (FMS Brilhante, FMS CR 1203, 1307, 1312 and 1326) under different osmotic potentials $(0,-0.2,-0.4,-0.5$ and $-0.6 \mathrm{MPa})$

When the seeds were treated at 0.0 and $-0.2 \mathrm{MPa}$, no difference in root length was noted among the crambe genotypes (Figure 3A). However, osmotic potential values equal or greater than $-0.4 \mathrm{MPa}$ resulted in longer root length for FMS CR 1203. Although the increase of root length immature plants submitted to water deficit is a common morphological change (Pimentel, 2004), in seedlings this response varies according to the species/genotype, as reported by Zhu et al. (2006), Paiva et al. (2018) and Almeida et al. (2018), studying the germination and early growth of Pinus sylvestris var. mongolica, Vigna unguiculata L. Walp and Coffea arabica L., respectively. In this study, higher root length was obtained for the FMS CR 1203 genotype treated at -0.6 MPa compared to the other genotypes, which was similar to the values obtained under control conditions. According to Echer et al. (2010), seedlings with the ability to grow roots under water stress conditions can maintain the hydration of tissues through osmotic adjustment. These results indicate higher growth capacity of the root system in order to improve water absorption (Ávila et al., 2007). 

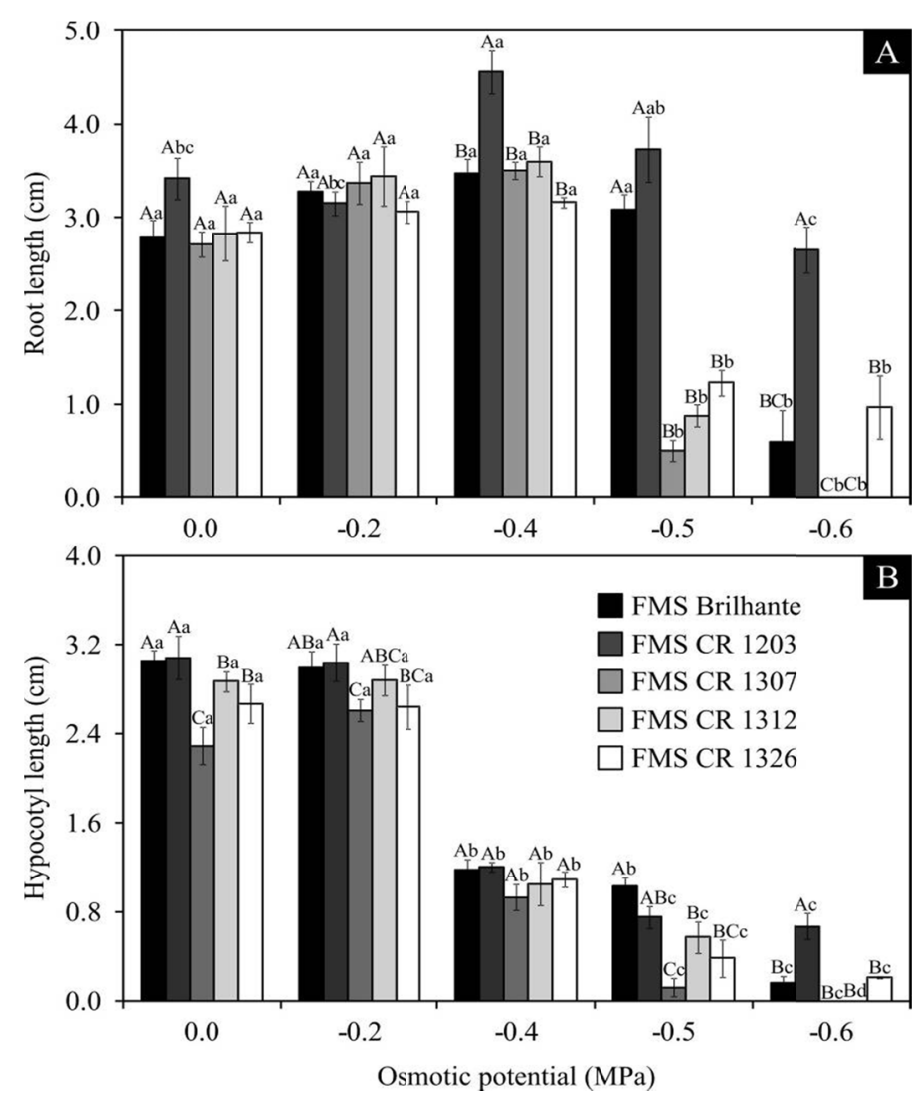

Figure 3. Root length (A) and hypocotyl length (B) of Crambe abyssinica Hochst. seedlings, genotypes FMS Brilhante, FMS CR 1203, 1307, 1312 and 1326, under different osmotic potentials. SD is shown, the same letters mean no significant difference (small letter: osmotic potentials, capital letter: different genotypes) $(p \leq 0.001)$

In this study, hypocotyl length was also affected by water deficit (Figure 3B). The FMS CR 1307 and 1312 genotypes showed no hypocotyl growth when the seeds were treated at $-0.6 \mathrm{MPa}$. These results were consistent with those obtained for the percentage of normal plants (Figure 1B). Reductions in hypocotyl length have also been reported for all these crambe genotypes subjected to osmotic potential values equal to or greater than -0.4 $\mathrm{MPa}$, suggesting a reduction in the water potential of plant cells and, however, a decrease in the pressure, expansion and cell growth, which limits the development of the seedlings (Jaleel et al., 2009). In contrast, the FMS CR 1203 genotype showed greatest hypocotyl length at the osmotic potential of $-0.6 \mathrm{MPa}$. This result can be attributed to the higher values of root growth reported for this genotype under water deficit (Figure 3A), indicating higher hydration of the tissue through osmotic adjustment, as reported by Echer et al. (2010).

The total fresh matter values decreased when the seedlings were treated at osmotic potential values equal to or greater than -0.4 MPa for all genotypes (Figure 4A). FMS CR 1307 and 1312 showed the lowest total fresh matter values in all treatments, except for -0.2 and $-0.4 \mathrm{MPa}$. This result was corroborated by the lower dry mass accumulation observed for these genotypes (Table 2). In contrast, at $\Psi_{\mathrm{s}}-0.6 \mathrm{MPa}$, significantly higher total fresh matter values were obtained for FMS CR 1203 compared to the other genotypes, which also was evidenced by the higher dry mass accumulation (Table 2). 

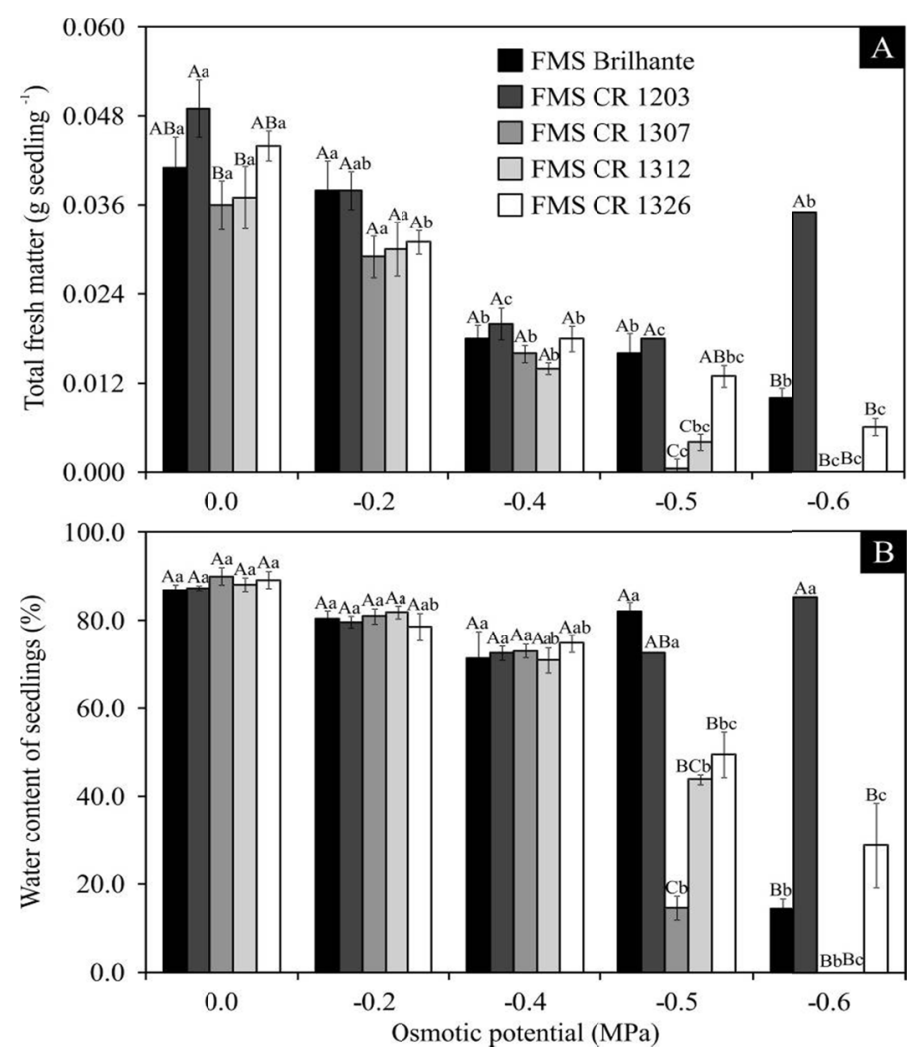

Figure 4. Total frech matter (A) and water content of seedlings (B) of Crambe abyssinica Hochst. seedlings, genotypes FMS Brilhante, FMS CR 1203, 1307, 1312 and 1326, under different osmotic potentials. SD is shown, the same letters mean no significant difference (small letter: osmotic potentials, capital letter: different genotypes) $(p \leq 0.001)$

According to Coelho et al. (2010), plant species have the ability to signal and regulate the protein expression when subjected to water stress, and consequently activate antioxidant enzymes such as peroxidase, catalase and ascorbate peroxidase and reduce the activity of superoxide dismutase, resulting in better reactive oxygen species elimination capacity under water deficit in seedlings, as observed by Ali et al. (2017), studying the effects of water deficit on germination and growth of bean seedlings (Vigna radiata L., cultivars NM-2006 and 8005). According to the authors, the better growth of seedlings is associated with a more efficient mechanism to eliminate reactive oxygen species, which is associated with both activity and content of antioxidant enzymes.

Table 2. Total dry matter of different genotypes Crambe abyssinica Hochst. under different osmotic potentials

\begin{tabular}{|c|c|}
\hline Osmotic potential (MPa) & Shoot dry matter $\left(\right.$ g seedling $\left.^{-1}\right)$ \\
\hline 0 & $0.0048 \pm 0.0010 \mathrm{~B}$ \\
\hline-0.2 & $0.0065 \pm 0.0011 \mathrm{~A}$ \\
\hline-0.4 & $0.0048 \pm 0.0007 \mathrm{~B}$ \\
\hline-0.5 & $0.0023 \pm 0.0020 \mathrm{C}$ \\
\hline-0.6 & $0.0019 \pm 0.0034 \mathrm{C}$ \\
\hline CV $(\%)$ & 36.9 \\
\hline Genotypes Crambe abyssinica & Shoot dry matter $\left(\right.$ g seedling $^{-1}$ ) \\
\hline FMS Brilhante & $0.0047 \pm 0.0031 \mathrm{AB}$ \\
\hline FMS CR 1203 & $0.0059 \pm 0.0010 \mathrm{~A}$ \\
\hline FMS CR 1307 & $0.0027 \pm 0.0023 \mathrm{D}$ \\
\hline FMS CR 1312 & $0.0030 \pm 0.0022 \mathrm{CD}$ \\
\hline FMS CR 1326 & $0.0040 \pm 0.0022 \mathrm{BC}$ \\
\hline CV (\%) & 36.9 \\
\hline
\end{tabular}

Note. Means followed by the same letter in the column do not differ by Tukey test at 0.001 probability level $( \pm \mathrm{SD})$. 
Under osmotic potential equal to or greater than $-0.5 \mathrm{MPa}$, reductions of water content were observed for all crambe genotypes except FMS Brilhante and FMS CR 1203 (Figure 4B). At $\Psi_{\mathrm{s}}=-0.6 \mathrm{MPa}$, higher water content values were obtained for FMS CR 1203, suggesting production and accumulation of several compounds, reducing the internal osmotic potential in order to maintain water uptake by seedlings (Manishankar et al., 2018), as well as the activation of enzymes for cell detoxification, as reported by Coelho et al. (2010) and Gupta and Huang (2014). In contrast, the reduction of water content indicates poor osmotic regulation. Osmotic adjustment maintains turgor and reduces growth sensitivity under water deficit conditions, causing low growth rate under stress (Meyer \& Boyer, 1981). Higher values of total dry matter were obtained at the osmotic potential of -0.2 MPa (Table 2). According to Carpiski et al. (2013), C. abyssinica Hochst is a species considered tolerant to water deficit and intolerant to excess moisture, indicating that osmotic potentials below $-0.2 \mathrm{MPa}$ are not adequate for germination of the studied genotypes. FMS CR 1203 showed the highest values of total dry matter, while FMS CR 1307 had the lowest values (-54.2\% compared to the highest dry matter value of FMS CR 1203).

Principal component analysis (PCA) was employed to assess the responses of each osmotic potential treatment and all the genotypes tested in all the data. PCA is a powerful method that converts the number of high-dimensional variables into a few numbers of principal components (PCs), representing the original data (Jolliffe \& Cadima, 2016). The results revealed that two principal components explained $91.5 \%$ of the total variance in the dataset, $72.9 \%$ in the first principal component (PC1), and $18.6 \%$ in the second (PC2) of the observed variability (Figure 5). Overall, the PCA revealed distinct clusters formed among the crambe genotypes proportional to their water potential, indicating the existence of a response pattern of seeds/seedlings of different crambe genotypes to variation in water potential conditions. Under low $\Psi_{\mathrm{w}}(0.0$ and $-0.2 \mathrm{MPa})$, the genotypes were clearly grouped in two clusters, in which the greatest difference was observed between FMS CR 1203 and FMS CR 1307. However, under high $\Psi_{\mathrm{w}}(-0.5$ and $-0.6 \mathrm{MPa})$, the FMS CR 1203 was grouped with all other genotypes submitted to $\Psi_{\mathrm{w}}=-0.4 \mathrm{MPa}$. Establishing principal components made it possible to show differences among the genotypes response to drought stress and under high $\Psi_{\mathrm{w}}$ FMS CR 1203 demonstrates a better performance to tolerate these conditions.

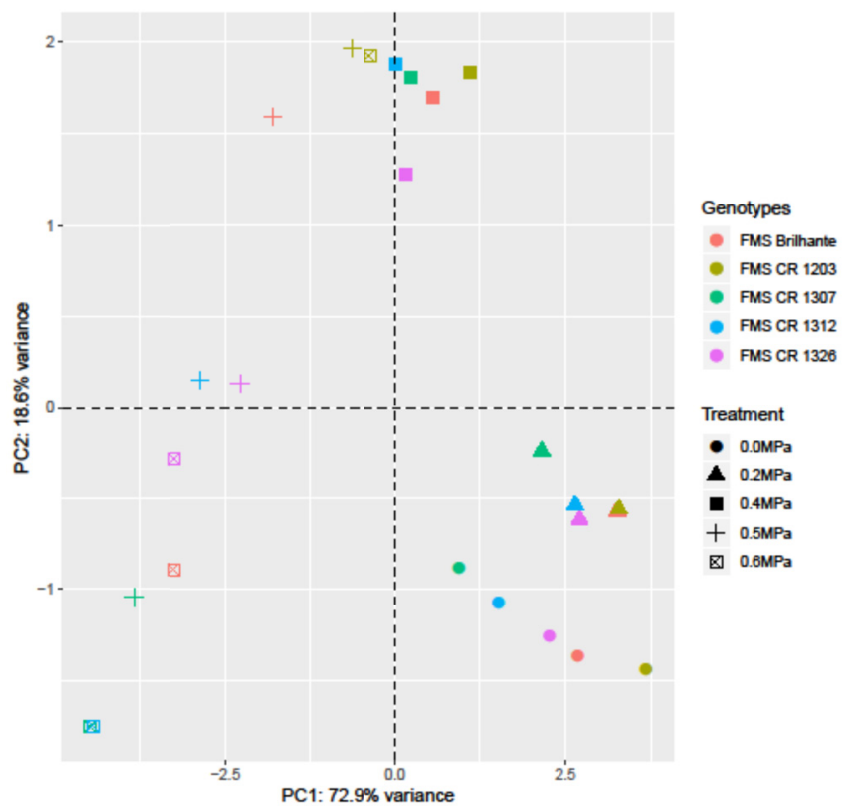

Figure 5. PCA-Principal component analysis generation plot considering all osmotic potentials treatments and the genotypes of Crambe abyssinica, FMS Brilhante, FMS CR 1203, 1307, 1312 and 1326

The results obtained in this study suggest the existence of significant genetic differences among the crambe genotypes studied in response to water deficit induced by polyethylene glycol. All genotypes evaluated were obtained through natural selection, so FMS CR 1203, 1307, 1312 and 1326 are natural crosses of different genotypes from the genotype FMS Brilhante. According to Kappes et al. (2010), the seed germination at different $\Psi$ s values depends on the genetic material used, whereby genotype is a determinant factor for tolerance or susceptibility to water deficit under field conditions. Attention is necessary to choose genotypes that are 
tolerant to water deficit (Machado et al., 2017). Thus, the results obtained in this study are relevant to evaluate the behavior of crambe genotypes under critical osmotic potentials for germination and early growth of seedlings. Finally, the PCA analysis corroborated the higher stress tolerance previously observed for FMS CR 1203, because even when increasing the intensity of water deficit, no differences in germination and seedling growth were noted. Furthermore, the grouping of FMS CR 1307 and 1312 corroborates the lower tolerance to water deficit.

\section{Conclusions}

The physiological quality of seeds and initial development of crambe genotypes are improved by $\Psi_{\mathrm{w}}=-0.2 \mathrm{MPa}$ and germination and vigor index of crambe seeds are hampered by the reduction in the potential to - $0.4 \mathrm{MPa}$. The genotype FMS CR 1203 is the most tolerant to water stress, whereas FMS CR 1307 and 1312 are the most sensitive.

\section{Acknowledgements}

The authors would like to acknowledge the scholarship awarded by the FAPES (Espírito Santo State Research Foundation). The authors are also grateful to the Mato Grosso do Sul Foundation for supplying the initial plant material.

\section{References}

Ali, Q., Javed, M. T., Noman, A., Haider, M. Z., Waseem, M., Iqbal, N., ... Perveen, R. (2017). Assessment of drought tolerance inmung bean cultivars/lines as depicted by the activities of germination enzymes, seedling's antioxidative potential and nutrient acquisition. Archives of Agronomy and Soil Science, 64(1), 84-102. https://doi.org/10.1080/03650340.2017.1335393

Almeida, J. A. S., Azevedo, M. T. V. L. G., Salomon, M. V., \& Medina, P. F. (2018). Water stress in germination, growth and development of coffee cultivars. Journal of Seed Science, 40(1), 082-089. https://doi.org/10.1590/2317-1545v40n176667

Ávila, M. R., Braccini, A. L., Scapim, C. A., Fagliari, J. R., \& Santos, J. L. (2007). Influence of manitol-induced water stress on canola seed germination and seedling growth. Revista Brasileira de Sementes, 29(1), 98-106. https://doi.org/10.1590/S0101-31222007000100014

Bewley, D. (1997). Seed germination and dormancy. Plant Cell, 9(7), 1055-1066. https://doi.org/10.1105/ tpc.9.7.1055

Bewley, J. D., \& Black, M. (1994) Seeds: Physiology of development and germination. Plenum Press. https://doi.org/10.1007/978-1-4899-1002-8

Bewley, J. D., Bradford, K. J., Hilhorst, H. W. M., \& Nonogaki, H. (2013). Seeds: Physiology of development, germination and dormancy (3rd ed.). Springer. https://doi.org/10.1007/978-1-4614-4693-4

Bove, J., Jullien, M., \& Grappin, P. (2001). Functional genomics in the study of seed germination. Genome Biology, 3(1), 1002.1-1002.5. https://doi.org/10.1186/gb-2001-3-1-reviews1002

Brasil, Ministério da Agricultura, Pecuária e Abastecimento, Secretaria de Defesa Agropecuária. (2009). Regras para análise de sementes. Brasília: MAPA.

Bruni, F. B., \& Leopold, A. C. (1992). Cytoplasmic glass formation in maize embryos. Seed Science Research, 2(4), 251-253. https://doi.org/10.1017/S0960258500001446

Cardoso, R. B., Binotti, F. F. da S., \& Cardoso, E. D. (2012). Physiologic potential of crambe seeds according to packaging and storage. Pesquisa Agropecuaria Tropical, 42(3), 272-278. https://doi.org/10.1590/S1983-40 632012000300006

Carlsson, A. S., Clayton, D., Salentiijn, E., \& Toonen, M. (2007). Oil crop platforms for industrial uses. Project Reports: EPOBIO Realising the Economic Potential of Sustainable Resources-Bioproducts from Non-food Crops.

Carpiski, M., Santos, R. F., Primieri, C., Silveira, L., Bassegio, D., Tomassoni, F., \& Nakai, E. H. (2013). Sensitivity of crambe (Crambe abyssinica) changes in groundwater level. Acta Iguazu, 2(4), 36-45.

Coelho, D. L. M., Agostini, E. A. T., Guaberto, L. M., Machado Neto, N. B., \& Custódio, C. C. (2010). Differential protein expression during germination as a result of a water deficit associated with variable osmotic pressure in snap-beans. Acta Scientiarum Agronomy, 32(3), 491-499. 
Dell'Aquila, A. (1992). Water uptake and protein synthesis in germinating wheat embryos under osmotic stress of polyethylene glycol. Annals of Botany, 69(2), 167-171. https://doi.org/10.1093/oxfordjournals.aob. a088322

Echer, F. R., Custódio, C. C., Hossomi, S. T., Dominato, J. C., \& Machado Neto, N. B. (2010). Water stress induced by mannitol in cotton cultivars. Revista Ciência Agronômica, 41(4), 638-645. https://doi.org/ 10.1590/S1806-66902010000400018

Faria, R. Q., Teixeira, I. R., Cunha, D. A., Honorato, J. M., \& Devilla, I. A. (2014). Physiological quality of crambe seeds submitted to drying. Revista Ciência Agronômica, 45(3), 453-460. https://doi.org/10.1590/ S1806-66902014000300004

Ferreira, D. F. (2011). Sisvar: A computer statistical analysis system. Ciência e Agrotecnologia, 35(6), 1039-1042. https://doi.org/10.1590/S1413-70542011000600001

Gill, P. K., Sharma, A. D., Singh, P., \& Bhullar, S. S. (2003). Changes in germination, growth and soluble sugar contents of Sorghum bicolor (L.) Moench seeds under various abiotic stresses. Plant Growth Regulation, 40(2), 157-162. https://doi.org/10.1023/A:1024252222376

Gupta, B., \& Huang, B. (2014). Mechanism of salinity tolerance in plants: Physiological, biochemical, and molecular characterization. International Journal of Genomics, 1-18. https://doi.org/10.1155/2014/701596

Jaleel, C. A., Manivannan, P., Washid, A. \& Panneerselvam, R. (2009). Drought stress in plants: A review on morphological characteristics and pigments composition. International Journal of Agriculture Biology, 11(1), 100-105.

Jolliffe, I. T., \& Cadima, J. (2016). Principal component analysis: A review and recent developments. Philosophical Transactions, Series A, 374(2065), 20150202. https://doi.org/10.1098/rsta.2015.0202

Kader, M. A., \& Jutzi, S. C. (2002). Temperature, osmotic pressure and seed treatments influence imbibition rates in sorghum seeds. Journal of Agronomy and Crop Science, 188(4), 286-290. https://doi.org/ 10.1046/j.1439-037X.2002.00581.X

Kappes, C., Andrade, J. A., Haga, K. I., Ferreira, J, P., \& Arf, M. V. (2010). Germination, seed vigor and seedling growth of corn on hidric stress conditions. Scientia Agraria, 11(2), 125-134. https://doi.org/ 10.5380/rsa.v11i2.16464

Kibinza, S., Vinel, D., Côme, D., Bailly, C., \& Corbineau, F. (2006). Sunflower seed deterioration as related to moisture content during ageing, energy metabolism and active oxygen species scavenging. Physiology of Plant, 128, 496-506. https://doi.org/10.1111/j.1399-3054.2006.00771.x

Machado, F. H. B., David, A. M. S. de S., Cangussú, L. V. S., Figueiredo, J. C., \& Amaro, H. T. R. (2017). Physiological quality of seed and seedling performance of crambe genotypes under water stress. Revista Brasileira de Engenharia Agrícola e Ambiental, 21(3), 175-179. https://doi.org/10.1590/1807-1929/ agriambi.v21n3p175-179

Maguire, J. D. (1962). Speed of germination aid in selection and evaluation for seedling emergence and vigor. Crop Science, 2, 176-77. https://doi.org/10.2135/cropsci1962.0011183X000200020033x

Manishankar, P., Wang, N., Köster, P., Alatar, F., \& Kudla, J. (2018). Calcium signaling during salt stress and in the regulation of ion homeostasis. Journal of Experimental Botany, 69(17), 4215-4226. https://doi.org/ $10.1093 / \mathrm{jxb} / \mathrm{ery} 201$

Marco- Filho, J. (2015). Seed vigor testing: An overview of the past, present and future perspective. Scientia Agricola, 72(4), 363-374.

Marcos-Filho, J. (2005). Fisiologia de sementes de plantas cultivadas. Piracicaba: FEALQ.

Meyer, R. F., \& Boyer, J. S. (1981). Osmoregulation, solute distribution, and growth in soybean seedlings having low water potentials. Planta, 151(5), 482-489. https://doi.org/10.1007/BF00386543

Noctor, G., \& Foyer, C. H. (1998). Ascorbate and glutathione: Keeping active oxygen under control. Annual Review of Plant Biology, 49, 249-279. https://doi.org/10.1146/annurev.arplant.49.1.249

Oliveira, R. C., Reis, A. C. C. S., Aguiar, C. G., Viecelli, C. A., Primieri, C., Tomasi, G. A., ... Viana, O. H. (2015). Agroindustrialização do Crambe. Cascavel: ASSOESTE. 
Paiva, E. P., Sá, F. V. S., Torres, S. B., Brito, M. E. B., Moreira, R. C. L., \& Silva, L. A. (2018). Germination and tolerance of cowpea (Vigna unguiculata) cultivars to water stress. Revista Brasileira de Engenharia Agricola e Ambiental, 22(6), 407-411. https://doi.org/10.1590/1807-1929/agriambi.v22n6p407-411

Patanè, C., Saita, A., \& Sortino, O. (2013). Comparative Effects of Salt and Water Stress on Seed Germination and Early Embryo Growth in Two Cultivars of Sweet Sorghum. Journal Agronomy of Crop Science, 199, 30-37. https://doi.org/10.1111/j.1439-037X.2012.00531.x

Pimentel, C. (2004). A relação da planta com a água. RJ: Edur, Seropédica.

Pitol, C., Broch, D. L., \& Roscoe, R. (2010). Tecnologia e produção: Crambe. Maracaju: Fundação MS.

Pitol, C., Broch, D. L. \& Roscoe, R. (2012). Introdução e Melhoramento do crambe no Brasil, Tecnologia e produção: Crambe, FMS, Ed., Fundação MS.

R Core Team (2018). R: A language and environment for statistical computing. R Foundation for Statistical Computing, Vienna, Austria.

Le, S., Josse, J., \& Husson, F. (2008). Facto Mine R: An R Package for Multivariate Analysis. Journal of Statistical Software, 25(1), 1-18. https://doi.org/10.18637/jss.v025.i01

Silva, A. C., Suassuna, J. F., Melo, A. S., Costa, R. R., Andrade, W. L., \& Silva, D. C. (2017). Salicylic acid as attenuator of drought stress on germination and initial development of sesame. Revista Brasileira de Engenharia Agrícola e Ambiental, 21(3), 156-162. https://doi.org/10.1590/1807-1929/agriambi.v21n3 p156-162

Silva, J. B., Rodrigues, T. J. D., \& Vieira, R. D. (2006). Soybean seed performance submitted to different osmotic potentials in polietileneglycol. Ciência Rural, 36(5), 1634-1637. https://doi.org/10.1590/S0103-84 782006000500047

Silva, R. C., Grzybowski, C. R. S., \& Panobianco, M. (2016). Vigour in maize seeds: Influence on seedling development under conditions of salt stress. Revista Ciência Agronômica, 47(3), 491-499. https://doi.org/ 10.5935/1806-6690.20160059

Viçosi, K. A., Ferreira, A. A. S., Oliveira, L. A. B., \& Rodrigues, F. (2017). Simulated water stress in common bean, corn and soybean genotypes. Revista de Agricultura Neotropical, 4(5), 36-42. https://doi.org/ 10.32404/rean.v4i5.2194

Villela, F. A., Doni Filho, L., \& Sequeira, E. L. (1991). Table of osmotic potential as a function of polyethilene glycol 6000 concentration and temperature. Pesquisa Agropecuária Brasileira, 26(11-12), 1957-1968.

Zhang, J., Wang, H., Liao, S., \& Cui, K. (2018). Appropriate ultra-low seed moisture content stabilizes the seed longevity of Calocedrus macrolepis, associated with changes in endogenous hormones, antioxidant enzymes, soluble sugars and unsaturated fatty acids. New Forests, 50(3), 1-14. https://doi.org/10.1007/ s11056-018-9670-4

Zhu, J. K. (2001). Plant salt tolerance. Trends in Plant Science, 6(2), 66-71. https://doi.org/10.1016/ S1360-1385(00)01838-0

Zhu, J., Kang, H., Tan, H., \& Xu, M. (2006). Effects of drought stresses induced by polyethylene glycol on germination of Pinus sylvestris var. mongolica seeds from natural and plantation forests on sandy land. Journal of Forest Research, 11(5), 319-328. https://doi.org/10.1007/s10310-006-0214-y

\section{Copyrights}

Copyright for this article is retained by the author(s), with first publication rights granted to the journal.

This is an open-access article distributed under the terms and conditions of the Creative Commons Attribution license (http://creativecommons.org/licenses/by/4.0/). 